\title{
Granulocyte colony-stimulating factor use in a large British hospital: comparison with published experience
}

\author{
Received (first version): 12 -Apr-2010 \\ Accepted: $13-S e p-2010$
}

\begin{abstract}
${ }^{*}$
Granulocyte colony-stimulating factors (G-CSF) are high-cost agents recommended as prophylaxis of febrile neutropenia or as adjunctive treatment of severe neutropenic sepsis. Their use in high-risk situations such as acute myeloid leukaemia, acute lymphocytic leukaemia, myelodysplastic syndrome and stem cell transplantation is also indicated. Objective: This audit assessed the use of G-CSF within the Oncology and Haematology Service Delivery Unit at Guy's and St. Thomas' hospital (London, United Kingdom).

Methods: Patients who received G-CSF in April-May 2008 were identified retrospectively from the pharmacy labelling system, and chemotherapy front sheets, clinic letters and transplantation protocols were reviewed. Patients on lenograstim, in clinical trials or under non-approved chemotherapy protocols were excluded.

Results: A total of 104 G-CSF treatments were assessed. The most commonly treated malignancy was breast cancer (41.3\%), with docetaxel 100 $\mathrm{mg} / \mathrm{m}^{2}(34.6 \%)$ being the most frequent chemotherapy regimen. The chemotherapy intent was curative in $66.3 \%$ of cases. Pegfilgrastim was used in $73.1 \%$ of cases and primary prophylaxis was the most common indication (54.8\%). Stem cell transplantation was the first indication to meet the audit criterion (93.3\%), followed by primary prophylaxis $(89.5 \%)$. There was a considerable nonadherence for secondary prophylaxis $(6.7 \%)$. Conclusion: The overall level of compliance with the audit criteria was $72.1 \%$. The results for primary and secondary prophylaxis would have been different if FEC100 (fluorouracil, epirubicin,

cyclophosphamide) and docetaxel $100 \mathrm{mg} / \mathrm{m}^{2}$ had been considered a single chemotherapy regimen. Also, the lack of access to medical notes may have affected the reliability of the results for 'therapeutic' use.
\end{abstract}

Keywords: Hematopoietic Cell Growth Factors. Neutropenia. Clinical Audit. Drug Utilization Review. United Kingdom.

*Román PÉREZ VELASCO. MPharm, MSc. Research Assistant, Health Intervention and Technology Assessment Program. Department of Health, Ministry of Public Health. Nonthaburi (Thailand).

\author{
USO DE FACTOR ESTIMULANTE DE \\ COLONIAS DE GRANULOCITOS EN UN \\ GRAN HOSPITAL BRITÁNICO: \\ COMPARACIÓN CON LA EXPERIENCIA \\ PUBLICADA
}

\section{RESUMEN}

Los factores estimulantes de colonias de granulocitos (G-CSF) son agentes de alto coste recomendados en la profilaxis de la neutropenia febril o como tratamiento coadyuvante de sepsis neutropénica grave. También está indicado su uso en situaciones de alto riesgo, tales como leucemia aguda mieloide, leucemia linfocítica aguda, síndrome mielodisplásico y trasplante de células madre.

Objetivo: Este audit evaluó el uso de G-CSF en la unidad de dispensación de los servicios de oncología y hematología del Hospital Guy y St. Thomas (Londres, Reino Unido).

Métodos: Mediante el sistema de etiquetado de farmacia, se identificó retrospectivamente a los pacientes que recibieron G-CSF entre abril y mayo de 2008 y se revisaron las hojas de quimioterapia, las notas clínicas y los protocolos de trasplante. Se excluyó a los pacientes en lenogastrim, en ensayos clínicos o bajo protocolos de quimioterapia no aprobados.

Resultados: Se evaluó un total de 104 tratamientos de G-CSF. La neoplasia más comúnmente tratada fue el cáncer de mama (41,3\%), siendo el docetaxel $100 \mathrm{mg} / \mathrm{m}^{2}$ el régimen terapéutico más comúnmente utilizado $(34,6 \%)$. El objetivo terapéutico fue curativo en el 66,3\% de los casos. El pegfilgastrim se usó en el 73,1/ de los casos y la profilaxis primaria fue la indicación más frecuente $(54,8 \%)$. El trasplante de células madre fue la primera indicación en cumplir los criterios del audit $(93,3 \%)$, seguida de la profilaxis primaria $(89,5 \%)$. Hubo un incumplimiento considerable en la profilaxis secundaria $(6,7 \%)$.

Conclusión: El nivel total de cumplimiento en el audit fue del $72,1 \%$. Los resultados de profilaxis primaria y secundaria hubieran sido diferentes si el FEC100 (fluorouracilo, epirubicina, ciclofosfamida) y el docetaxel $100 \mathrm{~m} \mathrm{~g} / \mathrm{m}^{2}$ se considerasen como régimen de quimioterapia único. Asimismo, la falta de acceso a las notas clínicas puede haber afectado a la fiabilidad de los resultados de objetivo terapéutico.

Palabras clave: Factores de crecimiento de células hematopoyéticas. Neutropenia. Audit clínico. 
Revisión de utilización de medicamentos. Reino Unido.

\section{INTRODUCTION}

Granulocyte (G-CSF) and granulocyte-macrophage colony-stimulating factors (GM-CSF) are commonly used to assuage haematological toxicity, predominantly in primary and secondary prophylaxis of chemotherapy-induced neutropenia and febrile neutropenia. These agents also play an important role in stem cell transplantation. G-CSFs modulate the formation of granulocytes, mostly neutrophils, whereas GM-CSFs also control the formation of macrophages and eosinophils. ${ }^{1}$ Only three recombinant G-CSFs are available on the UK market: lenograstim, filgrastim and pegfilgrastim. ${ }^{2}$

In recent years, the American Society of Clinical Oncology (ASCO) and other organizations, such as the National Comprehensive Cancer Network (NCCN), the European Society of Medical Oncology (ESMO) and the European Organisation for Research and Treatment of Cancer (EORTC) have renovated or developed clinical guidelines for the use of colony-stimulating factors.

A a result, the Guy's and St. Thomas' hospital has also updated its G-CSF guidelines. Therefore, an audit was conducted with the following objectives: (a) to describe the patterns of use of G-CSF (proportion of G-CSF type and indications, and treatment duration with filgrastim), (b) to assess whether the use of G-CSF complies with audit criteria and standards developed after a comprehensive review of the recently published clinical guidelines

\section{METHODS}

Setting and study design

This audit retrospectively reviewed all chemotherapy patients on G-CSF within the Oncology and Haematology Service Delivery Unit (SDU) at Guy's and St. Thomas' NHS Foundation Trust (London, United Kingdom) for a period of two months (April-May 2008). Patients treated with lenograstim (non-formulary), included in clinical trials or receiving non-approved chemotherapy protocols were excluded from the study as these scenarios were not covered by the hospital guidelines. In addition, each different G-CSF course was considered an independent treatment in order to simplify the data analysis.

\section{Data collection}

Data was retrieved from the pharmacy labelling system (JAC, Basildon, United Kingdom) (number of patients who were dispensed G-CSF and number of dispensed doses), chemotherapy front sheets, transplantation protocols and clinic letters.

Additional data from JAC (January-March 2008) were necessary to determine whether the indication for G-CSF use in some patients was primary or secondary prophylaxis.

One hundred and twenty-nine patients that were dispensed G-CSF were identified through the pharmacy labelling system. One hundred and thirteen patients met the inclusion criteria for the study. This resulted in 120 independent G-CSF treatments. However, chemotherapy front sheets could not be obtained for 16 patients, which reduced the number of valid treatments to 104 (Figure 1). Two factors may explain these missing patient records: (a) patients were included in clinical trials and, therefore, their records were kept in a 'blind' clinical trial folder; and (b) patients were not receiving chemotherapy, thus their information was not recorded in chemotherapy front sheets.

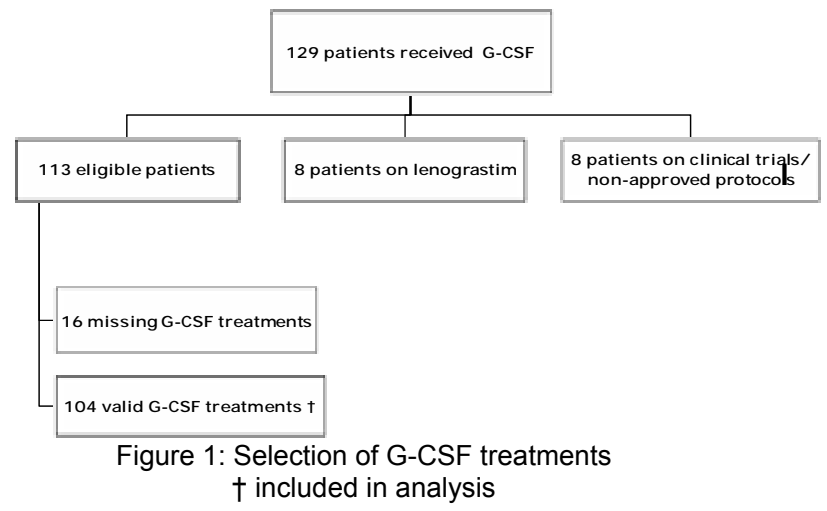

A data collection proforma was devised based on ASCO criteria adapted from the White Blood Cell Growth Factors (CSF) Orders and Flow Sheet. ${ }^{3}$ Additional data items were included based on other published audits. ${ }^{4-9}$ Recently updated clinical guidelines were also used to clarify or define some concepts. $^{10,11}$

In contrast with the ASCO guidelines, which do not opt for a specific G-CSF type, the hospital guidelines specifically recommend pegfilgrastim for primary and secondary prophylaxis (high risk situations, such as acute myeloid leukaemia (AML), acute lymphocytic leukaemia (ALL), myelodysplastic syndrome (MDS) and (stem cell transplantation (SCT)are considered primary prophylaxis) and filgrastim for febrile neutropenia (FN). Moreover, they differ in specifically advocating dose reductions or dose delays instead of G-CSF use in the palliative setting. ${ }^{12,13}$

\section{Audit criteria and standards}

Audit criteria were developed after a comprehensive review of the recently published clinical guidelines. Additionally, the hospital recommendations on the selection of G-CSF type were considered exceptions. $100 \%$ standards were selected for all criteria:

- Criterion for primary prophylaxis: considering the abovementioned high-risk situations different settings, use of pegfilgrastim following the synthesized recommendations ${ }^{10-12}$ (use of filgrastim was considered an exception). ${ }^{13}$ 


\begin{tabular}{|c|c|c|}
\hline Age & Mean & SD \\
\hline & 55 & 13 \\
\hline Gender & $\begin{array}{c}\text { Treatments } \\
(n=104)\end{array}$ & $\begin{array}{c}\% \text { of } \\
\text { treatments }\end{array}$ \\
\hline Female & 67 & 64.4 \\
\hline Male & 37 & 35.6 \\
\hline \multicolumn{3}{|l|}{ Primary tumour type } \\
\hline Breast & 43 & 41.3 \\
\hline Myeloma & 11 & 10.6 \\
\hline Small-cell lung cancer & 8 & 7.7 \\
\hline Other non-Hodgkin's lymphoma & 7 & 6.7 \\
\hline AML & 6 & 5.8 \\
\hline Diffuse large B-cell lymphoma & 5 & 4.8 \\
\hline Hodgkin's disease & 5 & 4.8 \\
\hline Germ cell & 4 & 3.8 \\
\hline Bladder & 3 & 2.9 \\
\hline Ovary & 2 & 1.9 \\
\hline Lung (non-specific) & 2 & 1.9 \\
\hline Other solid cancer & 2 & 1.9 \\
\hline Chronic lymphocytic leukaemia & 2 & 1.9 \\
\hline Other haematological disease & 3 & 2.9 \\
\hline Not documented & 1 & 1.0 \\
\hline \multicolumn{3}{|l|}{ Chemotherapy intent } \\
\hline Curative & 69 & 66.3 \\
\hline Palliative & 23 & 22.1 \\
\hline Not documented & 12 & 11.5 \\
\hline \multicolumn{3}{|l|}{ Place in therapy } \\
\hline Neo-adjuvant (solid) & 17 & 16.3 \\
\hline Adjuvant (solid) & 25 & 24.0 \\
\hline First line (solid) & 7 & 6.7 \\
\hline De novo (haematological) & 9 & 8.7 \\
\hline Refractory (haematological) & 3 & 2.9 \\
\hline Relapse (haematological) & 10 & 9.6 \\
\hline Not documented & 33 & 31.7 \\
\hline
\end{tabular}

- Criterion for secondary prophylaxis: use of pegfilgrastim in the curative setting following the synthesized recommendations ${ }^{10-12}$ (use of filgrastim was considered an exception). ${ }^{13}$

- Criterion for adjunctive treatment of established febrile neutropenia or 'therapeutic' use: use of filgrastim following the synthesized recommendations ${ }^{10-12}$ (use of pegfilgrastim was considered an exception). ${ }^{13}$

- Criterion for AML, ALL and MDS: use of pegfilgrastim following the synthesized recommendations ${ }^{10-12}$ (use of filgrastim was considered an exception). ${ }^{13}$

- Criterion for SCT: use of G-CSF following the

\begin{tabular}{|c|c|c|}
\hline Chemotherapy regimen & $\begin{array}{c}\text { Number of } \\
\text { treatments } \\
(n=104)\end{array}$ & $\begin{array}{c}\% \text { of } \\
\text { treatments }\end{array}$ \\
\hline Docetaxel $100 \mathrm{mg} / \mathrm{m}^{2}$ & $36 / 104$ & 34.6 \\
\hline Dose intense MVAC & 2/104 & 1.9 \\
\hline BEP & $3 / 104$ & 2.9 \\
\hline RCHOP-14 & $2 / 104$ & 1.9 \\
\hline RCHOP-21 & $3 / 104$ & 2.9 \\
\hline BEAM & $2 / 104$ & 1.9 \\
\hline FLAG-Ida & $4 / 104$ & 3.8 \\
\hline FEC100 & $3 / 104$ & 2.9 \\
\hline $\mathrm{AC}$ & $1 / 104$ & 1.0 \\
\hline Epirubicin & $1 / 104$ & 1.0 \\
\hline R-CVP & $2 / 104$ & 1.9 \\
\hline Carboplatin/etoposide & 9/104 & 8.7 \\
\hline Gemcitabine & $1 / 104$ & 1.0 \\
\hline Docetaxel 75 mg/m² & $3 / 104$ & 2.9 \\
\hline Carboplatin & $2 / 104$ & 1.9 \\
\hline LMB-86 & $2 / 104$ & 1.9 \\
\hline ABVD & $2 / 104$ & 1.9 \\
\hline ECX & $1 / 104$ & 1.0 \\
\hline Carboplatin/vinorelbine & $1 / 104$ & 1.0 \\
\hline Gemcitabine/cisplatin & $1 / 104$ & 1.0 \\
\hline Int dose melphalan/dexamethasone & $1 / 104$ & 1.0 \\
\hline Gemcitabine/carboplatin & $2 / 104$ & 1.9 \\
\hline Other & $20 / 104$ & 19.2 \\
\hline \multicolumn{3}{|c|}{$\begin{array}{l}\text { Abbreviations: ABVD: bleomycin, dacarbazine, doxorubicin, vinblastine; AC: doxorubicin, cyclophosphamide; BEAM: } \\
\text { carmustine, cytarabine, etoposide, melphalan; BEP: bleomycin, etoposide, cisplatin; ECX: epirubicin, cisplatin, capecitabine; } \\
\text { FEC: fluorouracil, epirubicin, cyclophosphamide; FLAG-Ida: G-CSF, fludarabine, cytarabine,idarubicin; LMB-86: COP, } \\
\text { COPADM-1, COPADM-2, CYVE, maintenance, IT; R-CHOP: rituximab, cyclophosphamide, doxorubicin, vincristine, } \\
\text { prednisolone; R-CVP: rituximab, cyclophosphamide, vincristine, prednisone. }\end{array}$} \\
\hline
\end{tabular}


synthesized recommendations ${ }^{12}$ (no exception was established, as the hospital transplantation protocols were being updated at the time of this study).

\section{Statistical analysis}

The data collected was quantitative and the statistical analysis was performed by SPSS version 16.0. Interval/ratio variables (age, G-CSF duration) were described by utilising mean and standard deviation. Nominal variables (all except for age and G-CSF duration) were described by utilising numbers and percentages. All the variables were descriptive and were measured by means of the 'frequencies' function in order to determine the prevalence of a variable.

\section{RESULTS}

The main characteristics of the study sample are described in Tables 1 and 2.

With regard to frequency of G-CSF type, pegfilgrastim was the most prevalent agent (76/104, $73.1 \%)$.

The use of G-CSF for primary prophylaxis represents the highest percentage $(57 / 104,54.8 \%)$. In 40 treatments $(n=104,38.5 \%)$, primary prophylaxis was prescribed because the $\mathrm{FN}$ risk associated with the used chemotherapy regimen was $\geq 20 \%$. In eleven treatments $(n=104,10.6 \%)$ the decision was based on the presence of one or more risk factors for infectious complications. Table 3 show the number of G-CSF treatments corresponding to each indication.

The mean duration of filgrastim therapy in established $\mathrm{FN}(\mathrm{n}=19)$ was six days $(\mathrm{SD}=4)$.

\begin{tabular}{|c|c|c|}
\hline Indication & $\begin{array}{l}\text { Treatments } \\
(n=104)\end{array}$ & $\begin{array}{c}\% \text { of } \\
\text { treatments }\end{array}$ \\
\hline $\begin{array}{ll}\text { Primary prophylaxis: } \\
\text { - } \quad \text { FN risk } \geq 20 \% \\
\text { Dose density } \\
-\quad \quad>65 \text { y.o./diffuse } \\
\text { aggressive } \\
\text { lymphoma/curative } \\
\text { chemotherapy } \\
\text { Higher risk for } \\
\text { infectious } \\
\text { complications }\end{array}$ & $\begin{array}{c}57 / 104 \\
40 / 104 \\
4 / 104 \\
2 / 104\end{array}$ & $\begin{array}{c}54.8 \\
38.5 \\
3.8 \\
1.9\end{array}$ \\
\hline Secondary prophylaxis & $15 / 104$ & 14.4 \\
\hline $\begin{array}{l}\text { 'Therapeutic' use in FN } \\
\text { (adjunct to antibiotics): }\end{array}$ & $10 / 104$ & 9.7 \\
\hline $\begin{array}{l}\text { High risk for } \\
\text { infectious } \\
\text { complications }\end{array}$ & 9/104 & 8.7 \\
\hline $\begin{array}{l}\text { Prognostic factors } \\
\text { of poor clinical } \\
\text { outcome }\end{array}$ & $1 / 104$ & 1.0 \\
\hline Adjunctive use in AML & $4 / 104$ & 3.8 \\
\hline $\begin{array}{l}\text { Adjunctive use in stem } \\
\text { cell transplantation }\end{array}$ & $15 / 104$ & 14.4 \\
\hline $\begin{array}{l}\text { Adjunctive use in } \\
\text { myelodysplastic } \\
\text { syndrome }\end{array}$ & $2 / 104$ & 1.9 \\
\hline Other (not in guidelines) & $1 / 104$ & 1.0 \\
\hline
\end{tabular}

\section{Compliance of G-CSF use with the audit criteria}

The level of compliance with the criterion for primary prophylaxis was high. In $89.5 \%$ of the cases (51/57), G-CSF (pegfilgrastim) was prescribed according to the audit criterion. Only six treatments were non-compliant. Three G-CSF treatments were given with docetaxel $75 \mathrm{mg} / \mathrm{m}^{2}$ in breast cancer and another treatment with ABVD (doxorubicin, bleomycin, vinblastine, dacarbazine) chemotherapy in Hodgkin's disease, which are not related to FN risk $\geq 20 \%$. The patients who received these treatments did not present high risk for infectious complications either. In two treatments the agent used was filgrastim. The level of compliance with the audit criterion for secondary prophylaxis was low. Only in $6.7 \%$ of the cases (1/15), G-CSF was prescribed appropriately.

A justification was found in $50.0 \%(5 / 10)$ of the GCSF treatments administered with a 'therapeutic' intention. Treatments with no documented risk for prognostic factors were considered unjustified.

An adherence of $50.0 \%(2 / 4)$ with the audit criterion was found for AML. However, the cause of nonadherence for the non-adherent to treatments was use of filgrastim instead of pegfilgrastim (given as per protocol). If these exceptions were included, the compliance would be $100 \%$.

No treatments were administered to patients with ALL. Two treatments were administered for MDS to the same patient (one with pegfilgrastim and another with filgrastim), but none of them was adherent to the audit criterion (no severe neutropenia).

The adherence to the audit criterion was almost complete in SCT $(93.3 \%, 14 / 15)$. G-CSF was given as recommended either in pre- or posttransplantation in most cases. Only one treatment $(n=15)$ given before allogeneic transplant was nonadherent. $80 \%(12 / 15)$ of G-CSF courses were given in autologous peripheral blood progenitor cell (PBPC) transplant. Of these treatments, $41.6 \%$ (5/12) were administered after stem cell return, $33.3 \%(3 / 12)$ prior to stem cell return, and for the rest of cases this information was not clearly documented. $20 \%(3 / 15)$ of G-CSF treatments were used to support allogeneic PBPC transplant. Of these treatments, $66.6 \%(2 / 3)$ were given after progenitor cell infusion (see Table 4).

\section{Other uses of G-CSF outside hospital guidelines}

In particular, there was a concern in the hospital about the use of G-CSF for secondary prophylaxis in lung cancer and breast cancer (with FEC100). It was found that there was a small departure from the audit criterion: only four out of 104 G-CSF treatments $(3.8 \%)$ were given for secondary prophylaxis in lung cancer. These treatments were palliative (except one, not documented). In addition, three G-CSF treatments ( $n=104,2.9 \%$ ) were used for secondary prophylaxis in breast cancer patients receiving FEC100. Of these treatments, one was in line with the audit criterion ( $33.3 \%$ compliance).

Apart from these uses, it is worth mentioning that chronic lymphocytic leukaemia (CLL) was the only 
Pérez Velasco R. Granulocyte colony-stimulating factor use in a large British hospital: comparison with published experience. Pharmacy Practice (Internet) 2010 Oct-Dec;8(4):213-219.

\begin{tabular}{|c|c|c|c|c|c|}
\hline Criterion & Exception & Standard & $\begin{array}{l}\text { No.treatments } \\
\text { meeting criterion }\end{array}$ & Compliance & Data source \\
\hline $\begin{array}{l}\% \text { G-CSF as primary } \\
\text { prophylaxis }\end{array}$ & Filgrastim & $100 \%$ & $\begin{array}{c}51 \\
(n=57)\end{array}$ & $\begin{array}{l}89.5 \% \\
91.2 \% \text { (if } \\
\text { exception } \\
\text { included) }\end{array}$ & $\begin{array}{l}\text { Chemotherapy front } \\
\text { sheets } \\
\text { Clinic letters }\end{array}$ \\
\hline $\begin{array}{l}\% \text { G-CSF treatments as } \\
\text { secondary prophylaxis }\end{array}$ & Filgrastim & $100 \%$ & $\begin{array}{c}1 \\
(n=15)\end{array}$ & $6.7 \%$ & $\begin{array}{l}\text { Chemotherapy front } \\
\text { sheets } \\
\text { Clinic letters } \\
\text { JAC from } 1 / 1 \text { to } 31 / 3 / 08\end{array}$ \\
\hline $\begin{array}{l}\% \text { G-CSF as 'therapy' in } \\
\text { established FN }\end{array}$ & Pegfilgrastim & $100 \%$ & $\begin{array}{c}5 \\
(n=10)\end{array}$ & $50.0 \%$ & $\begin{array}{l}\text { Chemotherapy front } \\
\text { sheets } \\
\text { Clinic letters }\end{array}$ \\
\hline $\begin{array}{l}\% \text { G-CSF as adjunctive } \\
\text { treatment of AML }\end{array}$ & Filgrastim & $100 \%$ & $\begin{array}{c}2 \\
(n=4)\end{array}$ & $\begin{array}{l}50.0 \% \\
100.0 \% \\
\text { (including } \\
\text { exception) } \\
\end{array}$ & $\begin{array}{l}\text { Chemotherapy front } \\
\text { sheets }\end{array}$ \\
\hline $\begin{array}{l}\% \text { G-CSF as adjunctive in } \\
\text { stem cell transplantation }\end{array}$ & None & $100 \%$ & $\begin{array}{c}14 \\
(n=15)\end{array}$ & $93.3 \%$ & $\begin{array}{l}\text { Chemotherapy front } \\
\text { sheets } \\
\text { Transplantation } \\
\text { protocols }\end{array}$ \\
\hline
\end{tabular}

non-recommended disease-specific use (1/104, $1 \%)$. However, CLL is a lymphoid leukaemia and could be considered a lymphoma. ${ }^{14}$

Moreover, it is possible that some of the G-CSF treatments, for which chemotherapy front sheets were missing, were administered to treat nonrecommended or non-approved conditions, especially haematological.

\section{DISCUSSION}

A limited number of G-CSF use reviews have been published in the literature. The number is even smaller for audits of compliance with clinical guidelines. However, three published audits may be used for comparison. ${ }^{6-8}$

In this audit, the most prevalent type of malignancy was breast cancer. All these patients were female. Despite this type of neoplasm being the most prevalent in the UK $(31 \%)^{15}$, it is important to note that almost all breast cancer patients were included in the study due to the high FN risk associated with docetaxel.

As opposed to the general population, myeloma was the second most prevalent malignancy. This may be due to the high number of stem cell transplantation procedures with G-CSF support performed in these patients.

$22.1 \%$ of G-CSF treatments were given in association with palliative chemotherapy. Although the ASCO guidelines do not distinguish between GCSF uses according to treatment intent, the hospital guidelines recommend dose reductions or dose delays instead of G-CSF use in the palliative setting. Although this hospital recommendation seems to be related to patient convenience and cost saving, it was incorporated into the criterion to evaluate the appropriateness of secondary prophylaxis.

In general, G-CSF type complies with the hospital recommendations. Pegfilgrastim was used in most cases in which G-CSF prophylaxis was prescribed. Filgrastim was reserved for 'therapy' or SCT.
Several of the most used chemotherapy regimens are associated with $\mathrm{FN}$ risk $\geq 20 \%$ : docetaxel 100 $\mathrm{mg} / \mathrm{m}^{2}$ for breast cancer, FLAG-Ida (G-CSF, fludarabine, cytarabine, idarubicin) for AML, BEP (bleomycin, etoposide, cisplatin) for germ cell tumours, and dose intense MVAC (methotrexate, vinblastine, doxorubicin, cisplatin) for bladder tumours. Other regimens are administered in a 'dose-dense' fashion (R-CHOP-14-rituximab, cyclophosphamide, doxorubicin, vincristine, prednisolone) for aggressive large cell lymphoma. As a result, the use of G-CSF for primary prophylaxis was clearly the most common indication in the hospital $(57 / 104,54.8 \%)$. Compliance with the audit criterion was the second highest (52/57, $91.2 \%$ ), only after the use of G-CSF for progenitor cell transplantation. The audit by Selkirk only included G-CSF for prophylaxis or 'treatment' and primary prophylaxis was the most frequent indication (45\%). However, compliance with local guidelines was low in comparison with this audit. ${ }^{8}$ This low compliance may be related to the study design prior to the 2006 update of the ASCO guidelines, when the threshold for justified G-CSF use was reduced from $40 \%$ to $20 \% \mathrm{FN}$ risk. In the audit conducted by McBrien, the inclusion criteria was similar to that of this study, however its sample size was small $(n=12)$ and this was probably the reason why it did not detect any indication for primary prophylaxis. ${ }^{6}$

Secondary prophylaxis was the second most common indication $(15 / 104,14.4 \%)$, along with adjunctive use in progenitor cell transplantation. However, its use was much lower than in the audit by McBrien, where this indication encompassed $50 \%$ of the total cases $(6 / 12) .{ }^{6}$ This indication showed the greatest departure from the audit criteria $(1 / 15,6.7 \%$ compliance versus $6 / 6,50 \%$ compliance $^{6}$ ). This overuse of G-CSF may be attributed to physicians' concerns about the outcomes of cancer treatment if neutropenia occurs.

It is important to highlight that in McBrien's audit FEC100 and docetaxel $100 \mathrm{mg} / \mathrm{m}^{2}$ were considered a single regimen contrary to this audit. ${ }^{6}$ According to the PACS 01 trial, the risk for febrile neutropenia associated with FEC-Docetaxel is $11.2 \%$, 
significantly higher than the risk associated to FEC $(0-8.4 \%)$, but generally lower than that of docetaxel $100 \mathrm{mg} / \mathrm{m}^{2}$ alone (10-21\%). ${ }^{10-12,16}$ In Guy's and St. Thomas', G-CSF was administered once docetaxel $100 \mathrm{mg} / \mathrm{m}^{2}$ was started, because this chemotherapy agent was considered independent of FEC100. If FEC and docetaxel had been regarded to be a single regimen, the proportion of treatments for secondary prophylaxis would have been much higher, in detriment of that for primary prophylaxis. Likewise, the compliance with the criterion for secondary prophylaxis would have been low, because G-CSF would have been given on the basis of the independent FN risk of docetaxel 100 $\mathrm{mg} / \mathrm{m}^{2}$.Another point that needs consideration is the cost implications of this practice.

The percentage of 'therapeutic' G-CSF was $11.5 \%$ $(12 / 104)$ (in comparison with $14 \%$ and $25 \%$ ). ${ }^{6,8}$ In the majority of treatments, no prognostic factor of poor clinical outcome was documented. Most cases were considered to fall into the category of high risk for infectious complications (11/12, 91.6\%). The adherence to the audit criterion was $41.7 \%(5 / 12)$ for 'therapeutic' use. Lymphoma was the most common high-risk factor $(2 / 4,50.0 \%)$, followed by age $>65(1 / 4,25.0 \%)$ and comorbidities (1/4, $25.0 \%$ ). It is interesting to point out that compliance was $100 \%$ and $66.6 \%$ in the audits by McBrien and Selkirk, respectively. ${ }^{6,8}$ In these cases, the authors gained access to patient medical notes, probably allowing them to obtain more thorough information about FN episodes.

The mean duration of 'therapeutic use' of filgrastim was six days $(S D=4)$. This outcome measure was calculated by using the number of filgrastim vials dispensed per treatment per patient.. RodríguezEscobar et al also reported a mean duration of five days (range=1-21), whilst McBrien reported 16.7 days. ${ }^{6,7}$

It is possible that some of these doses of filgrastim were dispensed to patients, but not administered. Nevertheless, other studies suggest that the use of patient medical records does not provide further information. ${ }^{4}$ Adjunctive use of G-CSF in AML was only detected in $3.8 \%$ of cases (4/104), none of them for 'priming'. Although the proportion of this malignancy was higher in the audit sample $(6 / 104$, $5.8 \%$ ), two of the G-CSF treatments were administered in stem cell transplantation. The level of compliance with the audit criterion was $50.0 \%$. It is necessary to note that three AML patients received FLAG-Ida as chemotherapy regimen and its protocol was not updated to recommend pegfilgrastim).

Use of myeloid growth factors in SCT was considerably frequent $(15 / 104,14.4 \%)$, and had the greatest level of adherence to the audit criteria in our study. Whilst the published British audits do not discuss the compliance of this indication, the Spanish audit found total compliance. ${ }^{6-8}$ However, it is important to say that transplantation procedures generally follow detailed protocols that guarantee a high level of adherence.
The reliability of this audit may be influenced by the following limitations:

- Restricted access to medical notes

- Availability of clinic letters only for solid tumor patients.

- Incomplete information in chemotherapy front sheets.

- Impossibility of determining whether patients were receiving concurrent radiotherapy from chemotherapy front sheets (G-CSF is contraindicated with concomitant chemotherapy and radiotherapy).

- Method to calculate treatment duration with filgrastim

Therefore, the following recommendations should be considered in order to improve the use of G-CSF and practice-based research in the hospital:

1. Easier access to medical records.

2. Appropriate completion of chemotherapy front sheets.

3. FEC-docetaxel as one regimen for $\mathrm{FN}$ risk assessment.

4. Review of guidelines to improve their comprehensiveness and clarity.

5. Re-audit of G-CSF usage three to six months after the first group of changes have been put into practice. ${ }^{17}$ This re-audit may also aim to identify the potential cost savings associated with a more appropriate G-CSF prescribing.

\section{CONCLUSIONS}

The overall compliance with the audit criteria was $72.1 \%(75 / 104)$. However, it is possible that some data were not documented. When documentation of an event was missing, it was considered that the event did not occur. This lack of documentation mainly affected 'therapeutic' use of G-CSF. However, it is acknowledged that medical notes may be a poor source of information. Limitations associated with missing data in the available sources were corrected by consulting the transplantation protocols, and those relating to concurrent radiotherapy and duration of filgrastim are unlikely to alter the trend of the results.

Compliance was almost complete for primary prophylaxis and stem cell transplantation, but low for secondary prophylaxis and 'therapeutic' use. The results for primary and secondary prophylaxis are probably affected by considering FEC100 and docetaxel $100 \mathrm{mg} / \mathrm{m}^{2}$ independent regimens. The cost implications of this policy should be contemplated.

\section{ACKNOWLEDGEMENTS}

I would like to thank Sarah Clifford, Josephine Falade, Laura Cameron and Aamer Safdar for their guidance and review of this project, in particular, 
their useful suggestions regarding data collection and analysis.

\section{CONFLICT OF INTEREST}

No conflict of interest. This study was submitted towards partial fulfillment of the MSc in Clinical
Pharmacy, International Practice and Policy (School of Pharmacy, University of London). No direct funding was available for this project. Some financial help for MSc completion was granted by Obra Social Caja España.

\section{References}

1. Clark OA, Lyman GH, Castro AA, Clark LG, Djulbegovic B. Colony-stimulating factors for chemotherapy-induced febrile neutropenia: a meta-analysis of randomized controlled trials. J Clin Oncol. 2005;23:4198-4214.

2. BNF. British National Formulary. 54th ed. London: British Medical Association and Royal Pharmaceutical Society of Great Britain; 2007.

3. ASCO. White Blood Cell Growth Factors (CSF) Orders and Flow Sheet. [Online] Available from: http://jop.ascopubs.org/cgi/data/2/4/196/DC2/1 [accessed 12.4.08].

4. Baker J, McCune JS, Harvey RD 3rd, Bonsignore C, Lindley CM. Granulocyte colony-stimulating factor use in cancer patients. Ann Pharmacother. 2000;34:851-857.

5. Dernedde U, Chan S, Sykes H, Larkin J, Popat S, Gilbert D, Jones L, Chowdhury S. South West London Cancer Network (SWLCN) audit of patients with chemotherapy-induced febrile neutropenia (CIFN). J Clin Oncol. 2008; 26(Suppl): abstract 20653

6. McBrien B. Review of G-CSF use in Oncology and Haematology patients (abstract). Queen Elizabeth Hospital. London Pharmacy Education and Training. The Pfizer Project Awards 2007. [Online] Available from: http://www.londonpharmacy.nhs.uk/educationandtraining/prereg/pfizerProjectAwards2007/Bronagh\%20McBrien\%20Qu een\%20Elizabeth\%20Hospital.pdf [accessed 20.6.08]

7. Rodríguez-Escobar I, Sevilla-Azzati E, Rodríguez-Sagredo MA, Anaya-Turrientes M, Piedra -Sánchez F, Velaz-Suárez MA, Merino-Alonso J, Fraile-Clemente C, García-Silva A, Perea -Ramos S, Martínez-Hernández A, Castillo-Romera I, Torralba-Arranz A, Sánchez-Guerrero A, Bustamente-Álvarez A, López-Arranz, MC. [Multicentre utilisation study of haemopoietic growth factors]. Farm Hosp. 1998;22:109-125.

8. Selkirk R. An audit of compliance with North Glasgow G-CSF guidelines within the Beatson Oncology Centre (abstract). Western Infirmary Glasgow. Scottish Specialists in Pharmaceutical Public Health. The Pfizer Project Awards 2006. [Online] Available from: http://www.ssipph.scot.nhs.uk/Pfizer_2006/AN\%20AUDIT\%200F\%20COMPLIANCE\%20WITH\%20NORTH\%20GLASG OW\%20G.doc [accessed 20.6.08].

9. Saab YB, Sharaf L, Zeidan I, Bizri A. Filgrastim use: evaluation in cancer and critically ill non-cancer patients. Cancer Therapy. 2003; 1: 191-196. [Online] Available from: http://www.cancertherapy.org/CT1A/pdf/20\%20\%20Saab\%20et\%20al,\%20191-196\%20cop.pdf [accessed 23.06.08].

10. Aapro MS, Cameron DA, Pettengell R, Aapro MS, Cameron DA, Pettengell R, Bohlius J, Crawford J, Ellis M, Kearney N, Lyman GH, Tjan-Heijnen VC, Walewski J, Weber DC, Zielinski C, EORTC G-CSF Guidelines Working Party. EORTC guidelines for the use of granulocyte-colony stimulating factor to reduce the incidence of chemotherapy-induced febrile neutropenia in adult patients with lymphomas and solid tumours. Eur J Cancer. 2006;42:2433-2453.

11. NCCN. Clinical Practice Guidelines in Oncology. Myeloid Growth Factors. V.1.2008. Fort Washington, PA: National Comprehensive Cancer Network; 2008.

12. Smith TJ, Khatcheressian J, Lyman GH, Ozer H, Armitage JO, Balducci L, Bennett CL, Cantor SB, Crawford J, Cross SJ, Demetri G, Desch CE, Pizzo PA, Schiffer CA, Schwartzberg L, Somerfield MR, Somlo G, Wade JC, Wade JL, Winn RJ, Wozniak AJ, Wolff AC. 2006 Update of recommendations for the use of white blood cell growth factors: An evidence-based clinical practice guideline. J Clin Oncol. 2006;24:3187-3205.

13.Yung L. Haematology and Oncology SDU Guidelines for the Use of Colony Stimulating Factors to Manage Neutropenia. London: Guy's and St. Thomas' NHS Foundation Trust; 2007.

14. Harris NL, Jaffe ES, Diebold J, Flandrin G, Muller-Hermelink HK, Vardiman J, Lister TA, Bloomfield CD.World Health Organization classification of neoplastic diseases of the hematopoietic and lymphoid tissues: report of the clinical advisory committee meeting-Arlie House, Va, November 1997. J Clin Oncol. 1999;17:3835-3849.

15. CRUK. CancerStats. Cancer Research UK. [Online] Available from: http://info.cancerresearchuk.org/cancerstats/reports/ [accessed 10.7.08].

16. Roché H, Fumoleau $P$, Spielmann M, Canon JL, Delozier T, Serin D, Symann M, Kerbrat $P$, Soulié $P$, Eichler $F$, Viens $P$, Monnier A, Vindevoghel A, Campone M, Goudier MJ, Bonneterre J, Ferrero JM, Martin AL, Genève J, Asselain B. Sequential adjuvant epirubicin-based and docetaxel chemotherapy for node-positive breast cancer patients: the FNCLCC PACS 01 trial. J Clin Oncol. 2006;24:5664-5671.

17. Ashmore $\mathrm{S}$, Johnson T. Analysing clinical audit data can reveal where change is needed. Pharmacy in Practice. 2006;(June-August):130-132. 